\title{
A comparison of molecular markers to detect Lutzomyia longipalpis naturally infected with Leishmania (Leishmania) infantum
}

\author{
Kárita Cláudia Freitas-Lidani ${ }^{1+}$, Iara J de Messias-Reason¹, Edna Aoba Y Ishikawa² \\ ${ }^{1}$ Laboratório de Imunopatologia Molecular, Departamento de Patologia Médica, Hospital de Clínicas, \\ Universidade Federal do Paraná, Curitiba, PR, Brasil ²Núcleo de Medicina Tropical, Universidade Federal do Pará, Belém, PA, Brasil
}

The aim of the present study was to detect natural infection by Leishmania (Leishmania) infantum in Lutzomyia longipalpis captured in Barcarena, state of Pará, Brazil, through the use of three primer sets. With this approach, it is unnecessary to previously dissect the sandfly specimens. DNA of $280 \mathrm{Lu}$. longipalpis female specimens were extracted from the whole insects. PCR primers for kinetoplast minicircle DNA (kDNA), the mini-exon gene and the small subunit ribosomal RNA (SSU-rRNA) gene of Leishmania were used, generating fragments of $400 \mathrm{bp}, 780 \mathrm{bp}$ and $603 \mathrm{bp}$, respectively. Infection by the parasite was found with the $\mathrm{kDNA}$ primer in $8.6 \%$ of the cases, with the mini-exon gene primer in $7.1 \%$ of the cases and with the SSU-rRNA gene primer in $5.3 \%$ of the cases. These data show the importance of polymerase chain reaction as a tool for investigating the molecular epidemiology of visceral leishmaniasis by estimating the risk of disease transmission in endemic areas, with the kDNA primer representing the most reliable marker for the parasite.

Key words: visceral leishmaniasis - Leishmania (Leishmania) infantum - Lutzomyia longipalpis

Leishmaniasis is a group of diseases caused by various species of the protozoan Leishmania and showing a wide range of clinical manifestations. Leishmaniasis represents a serious threat to public health in tropical and subtropical regions of several countries (Alvar et al. 2012) and is considered one of the most important neglected parasitic diseases (WHO 2010). Approximately two million new cases per year are estimated, with 350 million people at risk of contracting the disease.

Visceral leishmaniasis (VL) is a systemic and chronic disease that is fatal in cases that do not receive suitable treatment (Freitas-Junior et al. 2012). Brazil is one of the six countries that together include more than $90 \%$ of all recorded VL cases worldwide (Alvar at al. 2012); in this case, the disease is caused by Leishmania (Leishmania) infantum [syn. Leishmania (Leishmania) chagasi] (Kuhls et al. 2011). The sandfly Lutzomyia cruzi can be infected by L. (L.) infantum (Santos et al. 2003, Missawa et al. 2011), but the sandfly Lutzomyia longipalpis is considered the main vector (Lainson \& Rangel 2005).

The Brazilian VL control program is based on treating human cases, controlling vectors and reservoirs and euthanising seropositive infected dogs (MS/SVS/DVE 2006). One useful tool for epidemiological studies of leishmaniasis is the determination of the infection rate of parasites in sandflies (Kato et al. 2007).

doi: $10.1590 / 0074-0276130285$

Financial support: IEC, UFPA, FAPESPA, CNPq, CAPES

(032/2010 - National Incentive Program for Basic Research in Parasitology)

+ Corresponding author: kari.lidani@gmail.com

Received 28 May 2013

Accepted 2 June 2014
Several methods have been applied to detect infection in sandflies. Classical methods consist of searching for promastigotes in loco and isolating the parasite after the dissection of the digestive tract of the insect in a culture medium, which requires experience (Fernandes et al. 1994, Perez et al. 2007).

Molecular diagnostic assays, such as the polymerase chain reaction (PCR) assay, have been used for the identification and characterisation of Leishmania in vectors, especially in epidemiological field studies when a large number of samples need to be handled (Rodríguez 1999, Miranda et al. 2002). Different targets derived from nuclear and kinetoplast parasite DNA have been used to detect Leishmania spp in naturally infected phlebotomines. These targets include the rRNA gene, the miniexon-derived RNA gene, repeated genome sequences, glucose-6-phosphate dehydrogenase and the kinetoplast minicircle DNA (kDNA) minicircle (de Bruijin \& Barker 1992, Castilho et al. 2003, Paiva et al. 2006).

Because several markers are available to detect different genic regions of Leishmania, it is important to determine and compare their efficiency in identifying the parasite in epidemiological surveys. The present study aims to detect natural infections by $L$. (L.) infantum in Lu. longipalpis captured in Barcarena, state of Pará (PA), Brazil, and to compare the PCR amplification rate of three markers: kDNA, the mini-exon gene and the $18 \mathrm{~S}$ small subunit ribosomal RNA (SSU-rRNA) gene, with no previous dissection of the phlebotomine.

\section{MATERIALS AND METHODS}

Study area - The investigation was performed in northern Brazil in Santana do Cafezal $\left(0^{\circ} 3{ }^{\prime} 38.38^{\prime \prime}\right.$ S $\left.47^{\circ} 39^{\prime} 3.36^{\prime} \mathrm{W}\right), 7 \mathrm{~km}$ from the municipality of Barcarena (Fig. 1). According to the Köppen climate classification categories, Barcarena has a warm humid equatorial climate corresponding to the Amazon type of climate. 
The average annual temperature is approximately $27^{\circ} \mathrm{C}$. Abundant rainfall $(>2,500 \mathrm{~mm} /$ year) occurs more intensely in the first six months of the year (SEPOF-PA 2009). Approximately $80 \%$ of the population of Santana do Cafezal lives in wooden houses, with the remainder living in brick houses, next to vegetation and with domestic animal shelters nearby. The town has electricity, but has no basic sanitation and untreated water is commonly consumed.

Sandfly collections and species identification - Sandflies were captured between November 2003-February 2004, using CDC light traps placed overnight in peridomicile areas. The selection of the houses was based on previous entomological data as well as on the prevalence and incidence of human and canine cases of VL. The taxonomic identification of each specimen was determined according to Young and Duran (1994). In all, 280 female Lu. longipalpis were selected for molecular analysis.

DNA extraction - Total genomic DNA was extracted from sandflies following the Ready et al. (1997) method. Sandflies were macerated individually with a sterile tip in $1.5 \mathrm{~mL}$ tubes containing $100 \mu \mathrm{L}$ of grinding solution [0.1 M Tris- $\mathrm{HCl} \mathrm{pH}$ 7.5, 0.6 M NaCl, 0.1 M ethylenediamine tetraacetic acid (EDTA), $20 \mathrm{x}$ spermine/spermidine $\mathrm{mL}, 10 \%$ sucrose], $10 \mu \mathrm{L}$ of lysis buffer $(10 \%$ sodium dodecyl sulfate, $10 \%$ sucrose, $17 \mu \mathrm{L}$ diethylpyrocarbonate) and $30 \mu \mathrm{L}$ of $8 \mathrm{M}$ potassium acetate for protein precipitation. The DNA was precipitated with $96 \%$ ethanol and resuspended in $20 \mu \mathrm{L}$ of Tris-EDTA solution (10 mM Tris-HCl pH 8.0, 1 mM EDTA).

PCR assays - As a positive control for DNA extraction and to guarantee that all sandflies were correctly identified as $\mathrm{Lu}$. longipalpis, all sandflies were amplified by PCR using the primers Lul (5'-TGAGCTTGACTCTAGTTTGGCAC-3') and Lu2 (5'-AGATGTACCGCCCCAGTCAAA-3') that amplify a specific fragment for the 28S rRNA gene of Lu. longipalpis. The PCR, performed according to Cabrera et al. (2002), amplified a fragment of approximately $370 \mathrm{bp}$. For the identification of $L$. (L.) infantum, all positive samples were amplified with different primer pairs: D1/D2 for kDNA, S1629/S1630 for the mini-exon gene and R221/R332 for 18S SSU-rRNA gene. These primer pairs amplify fragments of $780 \mathrm{bp}, 400 \mathrm{bp}$ and $603 \mathrm{bp}$, respectively. PCR assays were performed as shown in Table I.

Sensitivity of PCR for different molecular targets To analyse the amplification capacity of the three targets (kDNA, SSU-rRNA and mini-exon), serial dilutions (1 fg to $100 \mathrm{ng}$ ) of $L$. (L.) infantum DNA (MCER/BR/1996/ M15677), extracted from culture, were tested singly and in the presence of sandfly DNA [the same serial dilutions of $L$. (L.) infantum DNA were added to each uninfected Lu. longipalpis DNA preparation $(30 \mathrm{ng} / \mu \mathrm{L})$ in triplicate assays]. The specificity test was performed to check the possibility of nonspecific fragments and consisted of amplifying Leishmania (Viannia) braziliensis and Leishmania (Leishmania) amazonensis DNA with the same PCR conditions used to amplify $L$. (L.) infantum DNA in Lu. longipalpis with kDNA, SSU-rRNA and mini-exon primers.

The PCR products were separated by horizontal electrophoresis on $1 \%$ agarose gel containing ethidium bromide $(0.5 \mu \mathrm{g} / \mathrm{mL})$ for $1 \mathrm{~h}$ at $100 \mathrm{~V}$. The amplification products were visualised under ultraviolet light.

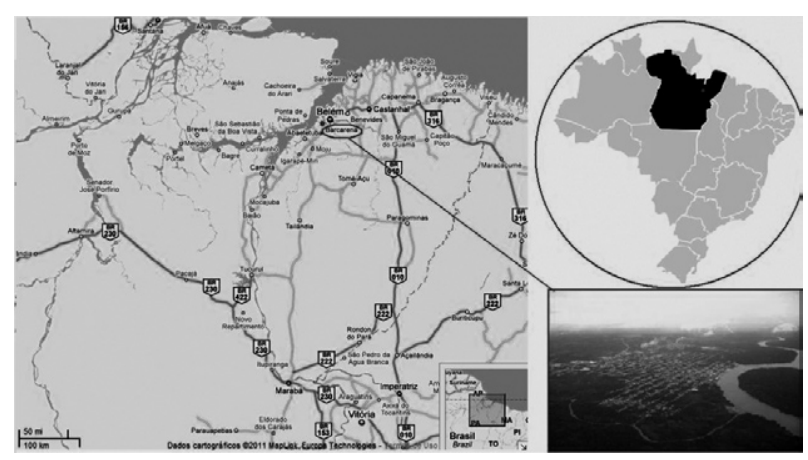

Fig. 1: map of the state of Pará and the municipality of Barcarena.

TABLE I

Genes and primer sequences used for the detection of Leishmania (Leishmania) infantum

\begin{tabular}{|c|c|c|c|}
\hline Gene & $\begin{array}{l}\text { Primer sequence } \\
\qquad\left(5^{\prime}-3^{\prime}\right)\end{array}$ & $\begin{array}{l}\text { Fragment } \\
\quad(\mathrm{bp})\end{array}$ & Reference \\
\hline kDNA & $\begin{array}{c}\text { D1/D2 } \\
\text { CCAGTTTCCCGCCCCG } \\
\text { GGGGTTGGTGGTGTAAAATAG }\end{array}$ & 780 & Smyth et al. (1992) \\
\hline Mini-exon & $\begin{array}{c}\text { S1629/S1630 } \\
\text { GGAATTCAATAWAGTACAGAAACTG } \\
\text { GGGAAGCTTCTGTACTWTATTGGTA }\end{array}$ & 400 & $\begin{array}{l}\text { Degrave et al. (1994), } \\
\text { Fernandes et al. (1994) }\end{array}$ \\
\hline SSU-rRNA & $\begin{array}{c}\text { R221/R332 } \\
\text { GGTTCCTTTCCTTGATTTAGC } \\
\text { GGCCGGTAAAGGCCGAATAG }\end{array}$ & 603 & Van Eyes et al. (1992) \\
\hline
\end{tabular}

kDNA: kinetoplast DNA; SSU-rRNA: small subunit ribosomal RNA. 


\section{RESULTS}

In the initial step, the effectiveness of genomic DNA extraction of sandflies was confirmed by the presence of a $370 \mathrm{bp}$ band (fragment of $28 \mathrm{~S}$ rRNA of $\mathrm{Lu}$. longipalpis) in all infected and non-infected sandfly samples (Fig. 2). The specificity test using primers D1/D2, S1629/S1630 and R221/R332 for different Leishmania strains [L. (V.) braziliensis, $L$. (L.) amazonensis and $L$. (L.) infantum] showed that all primer pairs are highly specific.

The sensitivity assay using serial dilutions of $L$. (L.) infantum DNA derived from culture showed an amplification of up to $10 \mathrm{pg}$ for kDNA, $100 \mathrm{pg}$ for the miniexon and $10 \mathrm{ng}$ for SSU-rRNA (Fig. 3). However, if $L$. (L.) infantum DNA derived from culture was mixed with sandfly genomic DNA (1:1), a significant decrease was observed in the sensitivity of two pairs of primers: the primer D1/D2 was able to detect 1 ng of DNA, and R221/ R332 was only able to detect up to $52.6 \mathrm{ng}$. The miniexon primer showed no change in the ability to detect $L$. (L.) infantum, amplifying up to $100 \mathrm{pg}$ even in the presence of Lu. longipalpis DNA (Fig. 4).

The PCR results for the Lu. longipalpis samples from Santana do Cafezal showed an infection rate of $8.6 \%$ using the D1/D2 primer, with the DNA from 24 of 280 female sandflies amplifying a fragment of $780 \mathrm{bp}$. In con-

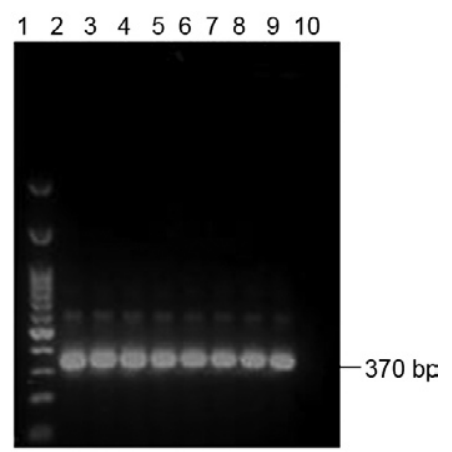

Fig. 2: polymerase chain reaction electrophoresis with amplified DNA of Lutzomyia longipalpis using primer for 28S rRNA gene. Lane 1: 50 bp DNA Ladder (Uniscience); 2-5: uninfected Lu. longipalpis; 6-9: infected Lu. longipalpis; 10: negative control. trast, the DNA from 20 sandflies amplified a fragment of 400 bp with the S1629/S1630 primer and the DNA from only 15 sandflies amplified a fragment of $603 \mathrm{bp}$ with the R221/R332 primer, resulting in infection rates of 7.1\% and $5.3 \%$, respectively (Fig. 5, Table II). When the PCR tests were combined, the following results were observed: $15 / 280(5.4 \%)$ infected sandflies were detected using the three markers, 20/280 (7.1\%) were detected using the 400 bp and 780 bp fragments, $15 / 280$ (5.4\%) were detected using the $400 \mathrm{bp}$ and $603 \mathrm{bp}$ fragments and 15/280 (5.4\%) were detected using the $603 \mathrm{bp}$ and $780 \mathrm{bp}$ fragments.

\section{DISCUSSION}

In this study, we evaluated the applicability of three PCR markers to the detection of Leishmania within sandflies, with no previous dissection of the phlebotomine. The primers used for the detection of the parasite with PCR for the mini-exon gene (S1629/S1630), the 18S rRNA gene (R221/R332) and kDNA (D1/D2) are well known and have been used in several studies to diagnose Leishmania infection in clinical specimens as well as in the identification of culture isolates, material from animals and infected sandflies (Aransay et al. 2000, Quinnell et al. 2001, Kaouech et al. 2008).
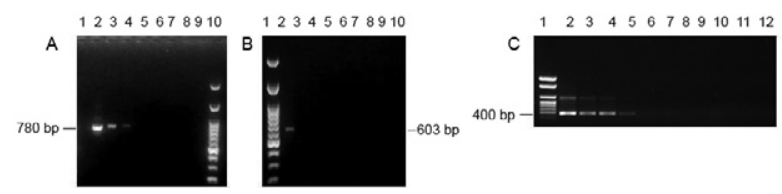

Fig. 4: polymerase chain reaction electrophoresis to evaluate the primer sensitivity using serial dilutions of Leishmania infantum DNA with Lutzomyia longipalpis DNA. A: primer D1/D2 [kinetoplast DNA (kDNA)] [Lane 1: negative control; 2-9 L. (L.) infantum DNA dilutions, respectively, of $52.6 \mathrm{ng} / \mu \mathrm{L}, 10 \mathrm{ng} / \mu \mathrm{L}, 1 \mathrm{ng} / \mu \mathrm{L}, 100 \mathrm{pg} / \mu \mathrm{L}, 10$ $\mathrm{pg} / \mu \mathrm{L}, 1 \mathrm{pg} / \mu \mathrm{L}, 100 \mathrm{fg} / \mu \mathrm{L}$ and $10 \mathrm{fg} / \mu \mathrm{L} ; 10: 100 \mathrm{bp}$ DNA Ladder (Kasvi)]; B: primer R221/R332 [small subunit ribosomal RNA (SSU rRNA)] [Lane 1: 100 bp DNA Ladder (Kasvi); 2-9 L. (L.) infantum DNA dilutions, respectively, of $52.6 \mathrm{ng} / \mu \mathrm{L}, 10 \mathrm{ng} / \mu \mathrm{L}, 1 \mathrm{ng} / \mu \mathrm{L}, 100$ $\mathrm{pg} / \mu \mathrm{L}, 10 \mathrm{pg} / \mu \mathrm{L}, 1 \mathrm{pg} / \mu \mathrm{L}, 100 \mathrm{fg} / \mu \mathrm{L}$ and $10 \mathrm{fg} / \mu \mathrm{L} ; 10$ : negative control]; C: primer S1629/S1630 (mini-exon) [Lane 1: 100 bp øX174/Hae III (Invitrogen); 2-11: $L$. (L.) infantum DNA dilutions, respectively, of $100 \mathrm{ng} / \mu \mathrm{L}, 10 \mathrm{ng} / \mu \mathrm{L}, 1 \mathrm{ng} / \mu \mathrm{L}, 100 \mathrm{pg} / \mu \mathrm{L}, 10 \mathrm{pg} / \mu \mathrm{L}, 1 \mathrm{pg} / \mu \mathrm{L}, 100 \mathrm{fg} /$ $\mu \mathrm{L}, 10 \mathrm{fg} / \mu \mathrm{L}$ and $1 \mathrm{fg} / \mu \mathrm{L} ; 12$ : negative control].
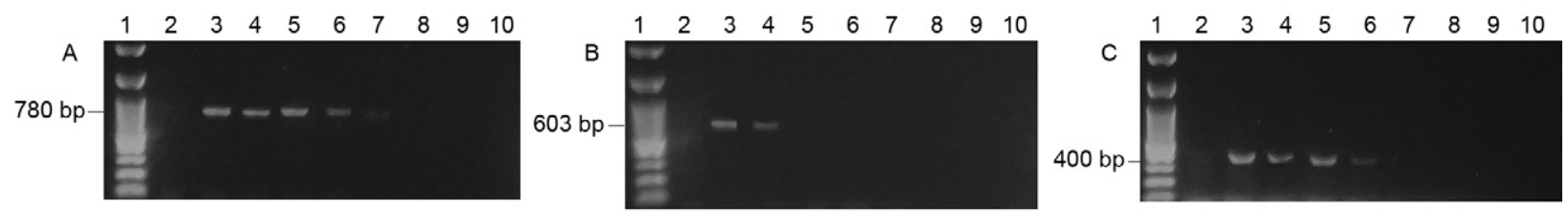

Fig. 3: polymerase chain reaction electrophoresis to evaluate the primer sensitivity using serial dilutions of Leishmania infantum DNA. A: primer D1/D2 [kinetoplast DNA (kDNA)] [Lane 1: 100 bp DNA Ladder (Kasvi); 2: negative control; 3-10: L. (L.) infantum DNA dilutions, respectively, of $100 \mathrm{ng} / \mu \mathrm{L}, 10 \mathrm{ng} / \mu \mathrm{L}, 1 \mathrm{ng} / \mu \mathrm{L}, 100 \mathrm{pg} / \mu \mathrm{L}, 10 \mathrm{pg} / \mu \mathrm{L}, 1 \mathrm{pg} / \mu \mathrm{L}, 100 \mathrm{fg} / \mu \mathrm{L}$ and $10 \mathrm{fg} / \mu \mathrm{L}$ ]; B: primer R221/R332 [small subunit ribosomal RNA (SSU rRNA)] [Lane 1: 100 bp DNA Ladder (Kasvi); 2: negative control; 3-10: L. (L.) infantum DNA dilutions, respectively, of $100 \mathrm{ng} / \mu \mathrm{L}, 10 \mathrm{ng} / \mu \mathrm{L}, 1 \mathrm{ng} / \mu \mathrm{L}, 100 \mathrm{pg} / \mu \mathrm{L}, 10 \mathrm{pg} / \mu \mathrm{L}, 1 \mathrm{pg} / \mu \mathrm{L}, 100 \mathrm{fg} / \mu \mathrm{L}$ and $10 \mathrm{fg} / \mu \mathrm{L}$ ]; C: primer S1629/S1630 (mini-exon) [Lane 1: $100 \mathrm{bp}$ DNA Ladder (Invitrogen); 2: negative control; 3-10: L. (L.) infantum DNA dilutions, respectively, of $100 \mathrm{ng} / \mu \mathrm{L}, 10 \mathrm{ng} / \mu \mathrm{L}, 1 \mathrm{ng} / \mu \mathrm{L}, 100 \mathrm{pg} / \mu \mathrm{L}, 10 \mathrm{pg} /$ $\mu \mathrm{L}, 1 \mathrm{pg} / \mu \mathrm{L}, 100 \mathrm{fg} / \mu \mathrm{L}, 10 \mathrm{fg} / \mu \mathrm{L}$ and $1 \mathrm{fg} / \mu \mathrm{L}]$. 

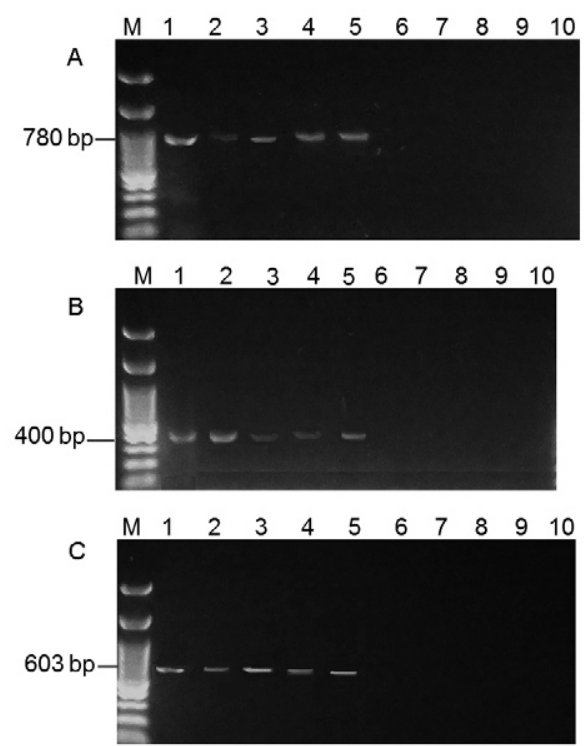

Fig. 5: detection of Leishmania (Leishmania) infantum in Lutzomyia longipalpis with kinetoplast DNA (kDNA), mini-exon and small subunit ribosomal RNA (SSU rRNA) targets. A: primer D1/D2 (kDNA) \{Lane 1: positive control [L. (L.) infantum DNA from culture]; 2-5: $L u$. longipalpis infected; 6-9: Lu. longipalpis non-infected; 10: negative control\}; B: primer R221/R332 (SSU rRNA) \{Lane 1: positive control [L. (L.) infantum DNA from culture]; 2-5: Lu. longipalpis infected; 6-9: Lu. longipalpis non-infected; 10: negative control\}; C: primer S1629/S1630 (mini-exon) \{Lane 1: positive control [L. (L.) infantum DNA from culture]; 2-5: Lu. longipalpis infected; 6-9: Lu. longipalpis non-infected; 10: negative control\}.

\section{TABLE II}

Infection natural rate to mini-exon, kinetoplast DNA (kDNA) and small subunit ribosomal RNA (SSU-rRNA) genes

\begin{tabular}{lccc}
\hline Targets & PCR+ & PCR- & $\begin{array}{c}\text { Infection rate } \\
(\%)\end{array}$ \\
\hline kDNA & 24 & 256 & 8.6 \\
Mini-exon & 20 & 260 & 7.1 \\
SSU-rRNA & 15 & 265 & 5.3 \\
\hline
\end{tabular}

The marker for kDNA clearly showed higher sensitivity when tested on culture samples $(10 \mathrm{pg})$. In contrast, primers R211/R332 and S1629/S1630 were only able to detect up to $100 \mathrm{pg}$ DNA. These results agree with previous studies that showed that the kDNA marker is able to detect as little as 1 fg of DNA (de Bruijin \& Barker 1992, Smyth et al. 1992).

Despite its low sensitivity in comparison with kDNA, the primer for the mini-exon gene has the advantage that in a single assay, it is possible to distinguish infection caused by $L$. (V.) braziliensis, $L$. (L.) amazonensis and $L$. (L.) infantum based only on the size of the fragment produced by PCR. The low sensitivity of the mini-exon gene primer is due to the number of DNA copies (Degrave et al. 1994) found inside the parasite.
When we tested the material extracted from sandflies captured in Santana do Cafezal, we observed that the frequency of infection detected in sandflies was $8.6 \%$ with the use of the primer D1/D2, a much higher rate than that found from the use of the S1629/S1630 and R221/R332 primers, whose sensitivity was $83.3 \%$ and $63 \%$, respectively. This difference may be related to the low number of parasites in each cell and the influence of possible inhibitors on the amplification process. All infections detected by the $400 \mathrm{bp}(\mathrm{n}=20)$ and $603 \mathrm{bp}(\mathrm{n}$ $=15$ ) fragments were also identified by the $780 \mathrm{bp}$ fragment, with no false positive samples for these markers.

Paiva et al. (2006) found a rate of 3.9\% of natural infection by $L$. (L.) infantum in the municipality of Antônio João, state of Mato Grosso do Sul, using the primer for the mini-exon gene. In a similar study in the same state, Silva et al. (2008) found an infection rate of $1.9 \%$ for VL in Campo Grande. Soares et al. (2010) observed rates of $1.25 \%$ for an old colonisation and $0.25 \%$ for a recent colonisation on São Luís Island (state of Maranhão) using primers for kDNA. Independent of the primer used, the infection rate observed in the present study, $8.6 \%$ for the kDNA gene, was greater than those reported from these previous studies in Brazil. Cimerman and Cimerman (2003) and Missawa et al. (2010) state that the infection ratio of Leishmania is usually low, even in endemic areas, with average values below 3\%. According to $\mathrm{Ci}$ merman and Cimerman (2003), transmission depends on the presence of high densities of Lu. longipalpis, as observed during outbreaks of the disease.

However, an infection rate of $19 \%(4 / 21)$ has been detected in Belo Horizonte (state of Minas Gerais) (Saraiva et al. 2010) based on the use of PCR for kDNA. The high rate observed might result from three factors: (i) the majority of samples were collected from the peridomicile, where several cases of VL occurred an year before the sampling, (ii) environmental conditions were favourable for the development of vectors, e.g., the high prevalence of canine infection, which is the most important source of infection for phlebotomines, and (iii) the molecular methods are sensitive and specific compared with traditional techniques of parasite visualisation.

de Oliveira et al. (2011) dissected 1,451 Lu. longipalpis females to evaluate the natural infection rate in Barcarena and found no infected flies. In contrast, Saraiva et al. (2010) found that the number of positive results based on the primer for kDNA was $500 \%$ greater than the value based on the intestinal dissection and microscopy of sandflies. This finding supports the reliability of kDNA in vectorial studies. Several authors, e.g., Degrave et al. (1994), Rodríguez et al. (1999) and Miranda et al. (2002), have also stated that molecular techniques are more sensitive and have greater specificity than the dissection method. The choice of techniques to investigate infection in sandflies is important because the different techniques can produce differing estimates of the true rates of natural infection.

Although research on individual samples may be more laborious, especially in large quantities, the great advantage over pooled samples is that a more realistic understanding of the frequency of infected sandflies oc- 
curring in peridomicile areas can be achieved, especially in areas where new cases are beginning to emerge in dogs and humans. The improved understanding that results from research on individual samples is informative for assessing the risk to the population. If the number of captured sandflies is high, the investigation should undoubtedly use pools of specimens and evaluate the minimum infection rate $\left(M R=n^{\circ}\right.$ of positive groups $\times 100 /$ total number of species).

These data show the importance of PCR as a tool for investigating the molecular epidemiology of VL and estimating the risk of disease transmission in endemic areas, with the primer for kDNA showing greater reliability as a marker for the parasite.

\section{ACKNOWLEDGEMENTS}

To Dr Adelson Alcimar Almeida de Souza (in memoriam) and to the technicians of the Instituto Evandro Chagas, for assisting our laboratory work.

\section{REFERENCES}

Alvar J, Velez ID, Bern C, Herrero M, Desjeux P, Cano J, Jannin J, den Boer M, the WHO Leishmaniasis Control Team 2012. Leishmaniasis worldwide and global estimates of its incidence. PLOS ONE 7: e35671.

Aransay AM, Scoulica E, Tselentis Y 2000. Detection and identification of Leishmania within naturally infected sand flies by PCR on minicircle kinetoplastic DNA. Appl Environ Microbiol 66: 1933-1938.

Cabrera OL, Munsterman LE, Cárdenas R, Gutiérrez R, Ferro C 2002. Definition of appropriate temperature and storage conditions in the detection of Leishmania DNA with PCR in phlebotomine flies. Biomedica 22: 296-302.

Castilho TM, Shaw JJ, Floeter-Winter LM 2003. New PCR assay using glucose-6-phosphate dehydrogenase for identification of Leishmania species. J Clin Microbiol 41: 540-546.

Cimerman S, Cimerman B 2003. Medicina tropical, 1st ed., Atheneu, São Paulo, 690 pp.

de Bruijin MHL, Barker DC 1992. Diagnosis of New World leishmaniasis: specific detection of species of the Leishmania braziliensis complex by amplification of kinetoplast DNA. Acta Trop 52: 45-58.

de Oliveira DMS, Saraiva EM, Ishikawa EAY, de Sousa AAA, da Silva EO, da Silva IM 2011. Distribution of phlebotomine fauna (Diptera: Psychodidae) across an urban-rural gradient in an area of endemic visceral leishmaniasis in northern Brazil. Mem Inst Oswaldo Cruz 106: 1039-1044.

Degrave W, Fernandes O, Campbell D, Bozza M, Lopes U 1994. Use of molecular probes and PCR for detection and typing of Leishmania - a mini-review. Mem Inst Oswaldo Cruz 89: 463-469.

Fernandes O, Murthy VK, Kurah U, Degrave W, Campbell DA 1994. Mini-exon gene variation in human pathogenic Leishmania species. Mol Biochem Parasitol 66: 261-271.

Freitas-Junior A, Chatelain E, Kim HA, Siqueira-Neto JL 2012. Visceral leishmaniasis treatment: what do we have, what do we need and how to deliver it? Int J Parasitol Drugs Drug Resist 2: 11-19.

Kaouech E, Kallel K, Toumi NH, Belhadj S, Anane S, Babba H, Chaker E 2008. Pediatric visceral leishmaniasis diagnosis in Tunisia: comparative study between optimised PCR assays and parasitological methods. Parasite 15: 143-150.

Kato H, Uezato H, Gomez EA, Terayama Y, Calvopiña M, Iwata H, Hashiguchi Y 2007. Establishment of a mass screening method of sand fly vectors for Leishmania infection by molecular biological methods. Am J Trop Med Hyg 77: 324-329.

Kuhls K, Alam MZ, Cupolillo E, Ferreira GEMF, Mauricio IL, Oddone R, Feliciangeli MD, Wirth T, Miles MA, Schönian G 2011. Comparative microsatellite typing of New World Leishmania infantum reveals low heterogeneity among populations and its recent Old World origin. PLoS Negl Trop Dis 5: el155.

Lainson R, Rangel EF 2005. Lutzomyia longipalpis and the eco-epidemiology of American visceral leishmaniasis, with particular reference to Brazil - A Review. Mem Inst Oswaldo Cruz 100: 811-827.

Miranda JC, Reis E, Schriefer A, Gonçalves M, Reis MG, Carvalho L, Fernades O, Barral-Netto M, Barral A 2002. Frequency of infection of Lutzomyia phlebotomines with Leishmania braziliensis in a Brazilian endemic area as assessed by pinpoint capture and polymerase chain reaction. Mem Inst Oswaldo Cruz 97: 185-188.

Missawa NA, Michalsky EM, Fortes-Dias CL, Dias ES 2010. Lutzomyia longipalpis naturally infected by Leishmania (L.) chagasi in Várzea Grande, Mato Grosso state, Brazil, an area of intense transmission of visceral leishmaniasis. Cad Saude Publica 26: 2414-2419.

Missawa NA, Veloso MA, Maciel GB, Michalsky EM, Dias ES 2011. Evidence of transmission of visceral leishmaniasis by Lutzomyia cruzi in the municipality of Jaciara, state of Mato Grosso, Brazil. Rev Soc Bras Med Trop 44: 76-78.

MS/SVS/DVE - Ministério da Saúde/Secretaria de Vigilância em Saúde/ Departamento de Vigilância Epidemiológica 2006. Manual de vigilância e controle da leishmaniose visceral, MS, Brasília, 182 pp.

Paiva BR, Secundino NFC, Nascimento JC, Pimenta PFP, Galati EAB, Andrade Junior HF, Malafronte RS 2006. Detection and identification of Leishmania species in field-captured phlebotomine sandflies based on mini-exon gene PCR. Acta Trop 99: 252-259.

Perez JE, Veland N, Espinosa D, Torres K, Ogusuku E, Llanos-Cuentas A, Gamboa D, Arévalo J 2007. Isolation and molecular identification of Leishmania (Viannia) peruviana from naturally infected Lutzomyia peruensis (Diptera: Psychodidae) in the Peruvian Andes. Mem Inst Oswaldo Cruz 102: 655-658.

Quinnell RJ, Courtenay O, Davidson S, Garcez L, Lambson B, Ramos P, Shaw JJ, Shaw M-A, Dye C 2001. Detection of Leishmania infantum by PCR, serology and cellular immune response in a cohort study of Brazilian dogs. Parasitology 122: 253-261.

Ready DP, Day JC, Souza AA, Rangel EF, Davies CR 1997. Mitochondrial DNA characterization of populations of Lutzomyia whitmani (Diptera, Psychodidae) incriminated in the peri-domestic and silvatic transmission in the of Leishmania species in Brazil. Bull Entomol Res 87: 187-195.

Rodríguez N, Aguilar CM, Barrios MA, Barker DC 1999. Detection of Leishmania braziliensis in naturally infected individual sandflies by the polymerase chain reaction. Trans $R$ Soc Trop Med Hyg 93: 47-49.

Santos SO, Arias JR, Hoffmann MP, Furlan MBG, Ferreira WF, Pereira C, Ferreira L 2003. The presence of Lutzomyia longipalpis in a focus of American visceral leishmaniasis where the only proven vector is Lutzomyia cruzi, Corumbá, Mato Grosso do Sul state. Rev Soc Bras Med Trop 36: 633-634.

Saraiva L, Andrade Filho JD, Silva SO, de Andrade ASR, Melo MN 2010. The molecular detection of different Leishmania species within sand flies from a cutaneous and visceral leishmaniasis sympatric area in southeastern Brazil. Mem Inst Oswaldo Cruz 105: 1033-1039.

SEPOF-PA - Secretaria de Estado de Planejamento, Orçamento e Finanças/Instituto de Desenvolvimento Econômico, Social e Ambiental do Pará 2009. Estatística municipal: Barcarena, 2009. Available from: iah.iec.pa.gov.br/iah/fulltext/georeferenciamento/barcarena.pdf. 
Silva EA, Andreotti R, Dias ES, Barros JC, Brazuna JCM 2008. Detection of Leishmania DNA in phlebotomines captured in Campo Grande, Mato Grosso do Sul, Brazil. Exp Parasitol 119: 343-348.

Smyth AJ, Gghosh A, Hassan MDQ, Basu D, de Bruijn M, Adhya S, Mallik KK, Barker DC 1992. Rapid and sensitive detection of Leishmania kinetoplast DNA from spleen and blood samples of kala-azar patients. Parasitology 105: 183-192.

Soares MRA, Carvalho CC, Silva LA, Lima MSCS, Barral AMP, Rebêlo JMM, Pereira SRF 2010. Análise molecular da infecção natural de Lutzomyia longipalpis em área endêmica de leishmaniose visceral no Brasil. Cad Saude Publica 26: 2409-2413.
Van Eys GJJM, Schoone GJ, Kroon CCM, Ebeling SB 1992. Sequence analysis of small subunit ribosomal RNA genes and its use for detection and identification of Leishmania parasites. Mol Biochem Parasitol 51: 133-142.

WHO - World Health Organization 2010. Control of the leishmaniasis: report of a meeting of the WHO Expert Committee on the Control of Leishmaniases. Available from: whqlibdoc.who.int/trs/WHO TRS_949_eng.pdf.

Young DG, Duran MA 1994. Guide to the identification and geographic distribution of Lutzomyia sand flies in Mexico, the West Indies, Central and South America (Diptera: Psychodidae). Memoirs Am Ent Inst 54: 1-881. 